\title{
ANTIOXIDANT AND ANTICONVULSANT EFFECTS OF MEDICINAL HERBS
}

\author{
Aldarmaa $\mathrm{J}^{\mathrm{a}}, \mathrm{J}_{\text {Liu }}$, J. Long ${ }^{\mathrm{b}}$, Nyamdalai $\mathrm{O}^{\mathrm{c}}$, Ariunaa $\mathrm{J}^{\mathrm{d}}$ \\ a Traditional Medicine, Science Technology Production Corporation, Ulaanbaatar, Mongolia \\ ${ }^{b}$ Institute for Nutritional Science, Shanghai Institutes for Biological Sciences, Chinese Academy of Sciences, \\ Shanghai 200031, People's Republic China, \\ "Hospital "Bolor melmiins", \\ "Institute of biochehnology, Ulaanbaatar, Mongolia
}

\begin{abstract}
s
This study examines the anticonvulsant profile of some medicinal plants (astragalus mongolicus, corydalis sibirica, scutellaria baicalensis and Chelidonium majus) and antioxidant effects of Astragalus mongolicus and Chelidonium majus. Astragalus mongolicus and Chelidonium majus extracts possessed a significant dose-dependent scavenging effect on hydroxyl and lipid radicals by an in vitro ESR technique. Astragalus mongolicus (150 and $300 \mathrm{mg} / \mathrm{kg}$ ) and Scutellaria baicalensis $(150$ and $300 \mathrm{mg} / \mathrm{kg}$ ) extracts had anticonvulsant activities in the Pentylenetetrazol (PTZ). Maximal Scutellaria baicalensis in a dose of 150 and $300 \mathrm{mg} / \mathrm{kg}$ significantly shortened the latency period seizures in the maximal electroshock (MES). Corydalis sibirica (150mg/kg) and Chelidonium majus (150 and $300 \mathrm{mg} / \mathrm{kg}$ ) extracts didn't influence on latency period in the PTZ and MES models. All extracts improved losing memory by passive avoidance task (longterm memory) and significantly didn't influence on drinking punishment in the Vogel's test.
\end{abstract}

Key words : Maximal electroshock, Pentylenetetrazol, hydroxyl radical, lipid radical.

\section{Introduction}

Stress is an internationally recognized phenomenon fortified by advancement of industrialization in a demanding civilization. Thus, every individual is likely to face stressful situations in day-to-day life. Stress represents a reaction of the body to a stimulus that tends to alter its normal physiological equilibrium or homeostasis and has been defined as a nonspecific response of the body to any demand imposed on it (Selye 1998). Since the introduction of the concept of adaptogens, several plants which were once used as tonics due to their rejuvenating properties in traditional medicine have been studied (Rege NN, Thatte UM, Dhanukar SA.. 1999). Drugs of plant origin are gaining increasing popularity and are being investigated for remedies of a number of disorders including antistress (adaptogenic) activity (Rubin JJ, 1980). The initial studies on Ocimum sanctum (Bhargava KP, Singh N. 1981) and Withania somnifera ( Singh HK, Dhawan BN. 1982) opened a vast area of research. Substantial work has been carried out on plants such as Eleuthrococcus 
senticosus and Panax ginseng (Warner $\mathrm{H}$, Norr $\mathrm{H}$ 1994). Stress can be described as the sum total of all the reactions of the body, which disturb the normal physiological condition and result in a state of threatened homeostasis.

Epilepsy is a chronic and important medical problem, with about one in eleven persons experiencing at least one seizure at some point. The tendency to have recurrent, unprovoked seizures occurs with a prevalence of about $0.5 \%$, and a cumulative lifetime prevalence of $3 \%$. It covers a range of different conditions with varying etiology (Hauser WA, Annegers JF, Kurland LT 1993). It has been reported that increased generation of free radicals or reduced activity of antioxidative defense mechanisms can cause some forms of seizures and, in addition, increase the risk of seizure recurrence (Maertens P, 1995, Ysksel A, 2000). Many antiepileptic drugs (AEDs) are metabolized to generate reactive metabolites with the capability of covalent binding to macromolecules including proteins or other vital biomolecules and hence eliciting systemic toxicity (Graf WD, 1198, Niketic V 1995,). Peroxidation of membrane lipids caused by an increase in the generation of free radicals or a decrease in the activities of antioxidant defense systems has been suggested to be critically involved in seizure control (Maertens P 1995).

It has been suggested that AEDs have occasionally been associated with significant adverse effects on the antioxidant defense system (Ybksel A, Cengiz M, 2000; Verrotti A, Basciani F, Trotta D 2002). The existing knowledge about the impact of epilepsy and AEDs on trace elements and the free radical /antioxidant system is scant and controversial.

Therefore, in this study, we evaluated the potential inhibitory effect of some extracts on free radicals and, further, investigated the neuropharmacological influence in commonly used behavioral tests.

Based on the accumulated legacy of knowledge from traditional medicine we selected medicinal herbs such as Chelidonium majus(Colombo ML 1996, Lenfeld J 1981), Corydalis sibirica, Astragalus mongolicus, Scutellaria baicalensis(Hamada H 1993, ).

\section{Methods}

\section{Ethical approval}

The experimental protocol was approved by the Institutional Animal Care and Ethical Committee of the Mongolian Health Ministry.

\section{Animals}

Mice and rats (The Centre of Traditional Medicine), weighing between 25-28g and $150-300 \mathrm{~g}$, were used in this study. Animals were housed in standard cages in groups of six in environmentally controlled conditions at a temperature of $22 \pm 2^{\circ} \mathrm{C}$ with a $2 \mathrm{hr}$ light $/ 12 \mathrm{hr}$ dark cycle. Throughout the experiment, animals were allowed free access to water and standard laboratory chow placed in separate containers. 


\section{Preparation of extract}

The aerial part of Chelidonium majus and Corydalis sibirica were collected from the Selenge aimak, Mongolia, in the month of July and were dried. The root of Astragalus mongolicus was collected from the Gachuurt district of Ulaanbaatar in the month of September and dried. The aerial parts of Astragalus mongolicus were collected from Gachuurt of Ulaanbaatar in early July. The dried powdered plant material $(5 \mathrm{~kg})$ was extracted with ethanol at $70^{\circ} \mathrm{C}$ for 7 days and the filtrate was evaporated in a vacuum drier at less than $70^{\circ} \mathrm{C}$ to give a final yield of $50 \mathrm{mg}$.

Scutellaria baicalensis was collected from Dornogovi aimak. The root of Scutellaria baicalensis and Astragalus mongolicus were soaked in cold water for 2 $\mathrm{hr}$, then cut into small pieces (less than $2 \mathrm{~mm}$ ). These pieces were soaked in ethanol at $70^{\circ} \mathrm{C}$ for 7 days. The filtrate obtained following ethanol extraction was evaporated under vacuum and lyophilized. During the experiment, the extract was dissolved in deionized water and centrifuged for $5 \mathrm{~min}$ (1200 rpm). The supernatant was used.

\section{Chemicals used}

Pentylenetetrazol (PTZ), DMPO, $F_{2}$. Other chemicals were all analytical purity reagents from local vendors.

\section{Behavioral tests:}

\section{Pentylenetetrazole (PTZ) Seizure model}

Mice were divided into groups of seven. Diazepam, extracts of medicinal herbs and normal saline were injected intraperitoneally (i.p) at 30 and $60 \mathrm{~min}$, respectively, before the administration of pentylenetetrazole (PTZ) (i.p, $110 \mathrm{mg} /$ $\mathrm{kg}$ ). The onset of a general clonus was used as the endpoint. The general clonus was characterized by forelimb clonus followed by full clonus of the body. The time taken before the onset of clonic convulsions, the duration of clonic convulsions, and the percentage of seizures and mortality were recorded (Vogel HG 1997, Kokate TG 1994).

\section{Maximal electroshock seizure (MES) model}

Mice were divided into groups of seven. An alternating current stimulus of 50 $\mathrm{Hz}$ and $150 \mathrm{~mA}$ was delivered through ear-clip electrodes for $0.2 \mathrm{sec}$ to the experimental animals. A drop of $0.9 \%$ saline solution was poured into each ear prior to placing the electrodes. Diazepam, carbenoxolone and normal saline were injected intraperitoneally (i.p) 30,60 and $60 \mathrm{~min}$, respectively before the test. The duration of tonic convulsion (a tonic extension of the hindlimb), the percentage of seizures and mortality were recorded (Vogel HG 1997).

\section{Punished Drinking (conflict situation) Test in Rats}


The procedure was a modification of that described by Vogel et al. (Vogel JR 1971). Rats, deprived of water for $48 \mathrm{~h}$ before testing, were placed in cages with a stainless steel grid floor. Each cage contained a drinking tube connected to a 50$\mathrm{ml}$ buret filled with tap water. Trials were started only when the animal's tongue had made contact with the drinking tube for the first time. An electric shock $(0.6 \mathrm{~mA} /$ $500 \mathrm{~ms}$ ) was delivered to the tongue after every twenty licks. The number of shocks was recorded during a 5-min period. Tests were performed 30 min after oral administration and i.p. injection of extracts and diazepam.

\section{Conditioned avoidance response test (CAR)}

The animals were placed in an illuminated box $(10413415 \mathrm{~cm})$ connected to a larger dark box (25 $420415 \mathrm{~cm}$ ) equipped with an electric grid floor. The animals entering the dark box were punished by an electric footshock $(0.6 \mathrm{~mA}$ for $2 \mathrm{~s}$ ). The mice that did not enter the dark compartment were excluded from the experiment. On the next day ( $24 \mathrm{~h}$ later), the pre-trained animals (without treatment) were placed again into the illuminated box and observed for up to $180 \mathrm{~s}$. Mice that avoided the dark compartment for $180 \mathrm{~s}$ were considered to remember the task. The time that elapsed before the mice entered the dark box was recorded and subsequently, the median latencies with 25 th and 75 th percentiles were calculated. The step-through passive avoidance task gives information about ability to acquire the task (learning) and to recall the task (retrieval). Therefore, it may be regarded as a measure of long-term memory (Vernualt $P$ 1986). This experimental procedure has been described in detail in our earlier study (Luszczki JJ 2003).

\section{ESR Analysis}

Lipid radical (Lя) and hydroxyl radical (.OH) were detected by ESR spectrometry in an in vitro system generating $\mathrm{L}$ and $\mathrm{OH}$ as described (GomezVargas $M, 1998$ ). The lipid radical ( $L$ ) was evaluated by the relative peak of signal of the 5,5-dimethyl-1-pyrroline- $\mathrm{N}$-oxide (DMPO)/ OH spin adduct to the intensity of $\mathrm{Cu}$ (II) used as an internal standard 3 min after mixing solutions containing $5 \mathrm{mM}$ $\mathrm{Cu}(\mathrm{II}), 15 \mathrm{MM} \mathrm{H}_{2} \mathrm{O}_{2}$, and $5 \mathrm{mM}$ DMPO . For detection of $\mathrm{OH}$, the signal intensity was evaluated by the relative peak of the second signal of the quartet of the DMPO/OH spin adduct to the intensity of $\mathrm{Fe}^{2+}$ used as an internal standard 3 min after mixing solutions containing $25 \mathrm{MM} \mathrm{FeSO}_{4}, 15 \mathrm{MM} \mathrm{H}_{2} \mathrm{O}_{2}$, and $5 \mathrm{mM}$ DMPO.

\section{Results}

\section{Antiepileptic effect}

The extract of Scutellaria baicalensis dose-dependently increased the latency of seizures ( $p<0.05$; Table 1$)$. However, it did not influence the duration of seizures.

The extract of Astragalus mongolicus increased the latency of PTZ-induced seizures and decreased the duration of seizures at doses of 150 and $300 \mathrm{mg} / \mathrm{kg}$ (Table 1). 
The extract of Corydalis sibirica decreased the latency and the duration of seizures at a dose of $300 \mathrm{mg} / \mathrm{kg}(P<0.05)$. However, a dose of $150 \mathrm{mg} / \mathrm{kg}$ extract of Corydalis sibirica increased the latency of seizures and decreased the duration of seizures. The extract of Chelidonium majus decreased the latency and the duration of seizures in a dose of $150 \mathrm{mg} / \mathrm{kg}$, while a dose of $300 \mathrm{mg} / \mathrm{kg}$ increased the latency and duration of seizures.(Table 1). A mixed extract of Scutellaria baicalensis and Astragalus mongolicus increased the latency of seizures in a dose of 150 and 300 $\mathrm{mg} / \mathrm{kg}$ and decreased the duration of seizures, yet this effect was not statistically significant for either dose of the mixed extract.

Table 1

Anticonvulsant effect of extracts of medicinal plants on the pentylenetetrazoleinduced convulsions in mice

\begin{tabular}{|c|c|c|c|c|c|}
\hline Treatment & Dose & $\begin{array}{c}\text { Onset of } \\
\text { seizure }(\mathrm{sec})\end{array}$ & $\begin{array}{l}\text { Duration of clonic } \\
\text { seizure (sec) }\end{array}$ & $\begin{array}{l}\text { Seizure } \\
\text { protection } \\
(\%)\end{array}$ & $\begin{array}{c}\text { Mortality } \\
\text { protection } \\
(\%)\end{array}$ \\
\hline Normal saline & $\begin{array}{l}10 \\
\mathrm{ml} / \mathrm{kg}\end{array}$ & $119.75 \pm 8.14$ & $659.75 \pm 100.27$ & 0 & 0 \\
\hline \multirow[t]{2}{*}{$\begin{array}{l}\text { Astragalus } \\
\text { mongolicus }\end{array}$} & $\begin{array}{l}150 \\
\mathrm{mg} / \mathrm{kg}\end{array}$ & $181 \pm 49.5^{*}$ & $353 \pm 49.13 *$ & 20 & 40 \\
\hline & $\begin{array}{l}300 \\
\mathrm{mg} / \mathrm{kg}\end{array}$ & $164 \pm 33.58^{*}$ & $365.25 \pm 88.5^{*}$ & 0 & 20 \\
\hline Diazepam & $\begin{array}{l}1 \\
\mathrm{mg} / \mathrm{kg}\end{array}$ & $439.61 \pm 60.80 * *$ & $4.7 \pm 1.67 * * *$ & 42.8 & 100 \\
\hline \multirow[t]{2}{*}{$\begin{array}{l}\text { Scutellaria } \\
\text { Baicalensis }\end{array}$} & $\begin{array}{l}150 \\
\mathrm{mg} / \mathrm{kg}\end{array}$ & $233.18 \pm 40.26 * *$ & $540 \pm 99.27$ & 31 & 0 \\
\hline & $\begin{array}{l}300 \\
\mathrm{mg} / \mathrm{kg}\end{array}$ & $261.2 \pm 84.38 * *$ & $511.4 \pm 111.64 *$ & 32 & 20 \\
\hline \multirow[t]{2}{*}{$\begin{array}{l}\text { Corydalis } \\
\text { sibirica }\end{array}$} & $\begin{array}{l}150 \\
\mathrm{mg} / \mathrm{kg}\end{array}$ & $122.11 \pm 23.29$ & $273 \pm 99.95$ & 0 & 0 \\
\hline & $\begin{array}{l}300 \\
\mathrm{mg} / \mathrm{kg}\end{array}$ & $73.9 \pm 31.24^{*}$ & $404.6 \pm 96.86$ & 0 & 0 \\
\hline \multirow[t]{2}{*}{$\begin{array}{l}\text { Chelidonium } \\
\text { majus }\end{array}$} & $\begin{array}{l}150 \\
\mathrm{mg} / \mathrm{kg}\end{array}$ & $82.2 \pm 35.1^{*}$ & $415.8 \pm 101.06$ & 0 & 0 \\
\hline & $\begin{array}{l}300 \\
\mathrm{mg} / \mathrm{kg}\end{array}$ & $132.75 \pm 38.26$ & $1276.27 \pm 261.71^{*}$ & 30. & 0 \\
\hline \multirow[t]{2}{*}{$\begin{array}{l}\text { ScBaic+Ast.Mon } \\
\text { golicus }\end{array}$} & $\begin{array}{l}150 \\
\mathrm{mg} / \mathrm{kg}\end{array}$ & $122.6 \pm 45.14$ & $349.4 \pm 95.06$ & 30 & 0 \\
\hline & $\begin{array}{l}300 \\
\mathrm{mg} / \mathrm{kg}\end{array}$ & $141.2 \pm 26.48$ & $756.4 \pm 98.06$ & 30 & 0 \\
\hline
\end{tabular}

Extract of medicinal plants and diazepam (i.p.) were injected 60 and 30 minutes respectively, before the administration of pentylenetetrazole (i.p. $110 \mathrm{mg} / \mathrm{kg}$ ). Values are the mean \pm SEM for 6 mice. ${ }^{*} P<0.05,{ }^{* *} P<0.01$, Compared to control, t-Student Test. 
In the maximal electroshock(MES) model, Scutellaria baicalensis significantly decreased the duration of tonic seizures. This extract completely protected the rats against mortality in doses of 150 and $300 \mathrm{mg} / \mathrm{kg}$ (Table 2). The extract of Chelidonium majus $(300 \mathrm{mg} / \mathrm{kg})$ decreased the duration of tonic seizures. In the lower dose of $150 \mathrm{mg} / \mathrm{kg}$ extract increased the duration of tonic seizures (Table 2). These effects were not statistically significant for either dose of extract. The extract of Astragalus mongolicus significantly decreased the duration of tonic seizures in a dose of $300 \mathrm{mg} / \mathrm{kg}$.. It could not completely protect the rats against mortality in a lower dose of $150 \mathrm{mg} / \mathrm{kg}$.

\section{Table 2}

Anticonvulsant effects of extracts against seizures induced by maximal electroshock in mice

\begin{tabular}{|c|c|c|c|c|}
\hline Treatment & Dose & $\begin{array}{l}\text { Duration of tonic } \\
\text { seizure }(\mathrm{sec})\end{array}$ & $\begin{array}{l}\text { Seizure } \\
\text { protection }(\%)\end{array}$ & $\begin{array}{l}\text { Mortality } \\
\text { protection (\%) }\end{array}$ \\
\hline $\begin{array}{l}\text { Normal } \\
\text { saline }\end{array}$ & $\begin{array}{l}10 \\
\mathrm{ml} / \mathrm{kg}\end{array}$ & $10.75 \pm 1.52$ & 0 & 20 \\
\hline Diazepam & $\begin{array}{l}0.5 \\
\mathrm{mg} / \mathrm{kg}\end{array}$ & $8.63 \pm 0.21^{*}$ & 0 & 100 \\
\hline $\begin{array}{l}\text { Chelidonium } \\
\text { majus }\end{array}$ & $\begin{array}{l}150 \\
\mathrm{mg} / \mathrm{kg}\end{array}$ & $11.25 \pm 1.51$ & 0 & 100 \\
\hline $\begin{array}{l}\text { Chelidonium } \\
\text { majus }\end{array}$ & $\begin{array}{l}300 \\
\mathrm{mg} / \mathrm{kg}\end{array}$ & $8.75 \pm 1.5$ & 0 & 100 \\
\hline $\begin{array}{l}\text { Normal } \\
\text { saline }\end{array}$ & $\begin{array}{l}10 \\
\mathrm{ml} / \mathrm{kg}\end{array}$ & $25.91 \pm 1.5$ & 0 & 20 \\
\hline $\begin{array}{l}\text { Astragalus } \\
\text { mongolicus }\end{array}$ & $\begin{array}{l}150 \\
\mathrm{mg} / \mathrm{kg}\end{array}$ & $20.66 \pm 3.97$ & 0 & 75 \\
\hline $\begin{array}{l}\text { Astragalus } \\
\text { mongolicus }\end{array}$ & $\begin{array}{l}300 \\
\mathrm{mg} / \mathrm{kg}\end{array}$ & $21.85 \pm 5.97$ & 20 & 100 \\
\hline $\begin{array}{l}\text { Scuttellaria } \\
\text { Baicalensis }\end{array}$ & $\begin{array}{l}150 \\
\mathrm{mg} / \mathrm{kg}\end{array}$ & $17.77 \pm 1.51^{*}$ & 0 & 100 \\
\hline $\begin{array}{l}\text { Scuttellaria } \\
\text { Baicalin }\end{array}$ & $\begin{array}{l}300 \\
\mathrm{mg} / \mathrm{kg}\end{array}$ & $17.47 \pm 1.71 * *$ & 14.3 & 100 \\
\hline
\end{tabular}

Extracts of Chelidonium majus, Astragalus mongolicus, and Scutellaria Baicalensis were administered (orally), and diazepam (i.p.) was injected 60 or 30 minutes, respectively, before the induction of maximal electroshock seizures. Values are the mean \pm SEM for 6 mice. ${ }^{*} P<0.05,{ }^{* *} P<0.01$, compared to controls, by Student's t-Test Anxiolytic effect 
When water-deprived animals were placed in the experimental chamber in the absence of shock, they licked without interruption throughout the test period (2 $\mathrm{min})$, totaling approximately 25 licking periods. When a $0.8 \mathrm{~mA}$ current to drinking tube was delivered after every $3 \mathrm{sec}$ of drinking, it reduced the number of licking periods significantly. This conflict situation is similar to the one described by Vogel et al.(???). We studied the anxiolytic effect of Chelidonium majus, the aerial part of Astragalus mongolicus and Corydalis sibirica by this test. It has previously been reported that the root of Astragalus mongolicus and Scutteliria baicalensis cause an anxiolytic effect (). Therefore, we did not test the effect of these herbs in this experiment.

Corydalis sibirca did not elicit an anticonflict effect in a dose of 75 and $150 \mathrm{mg} / \mathrm{ml}$. After administration of extracts the number of punished drinking episodes was not changed as compared to the control group (Table 3). Also, the aerial part of Astragalus mongolicus did not influence the number of punished drinking episodes in doses of 75 and $150 \mathrm{mg} / \mathrm{ml}$. However, an anticonflict effect was detected in extracts of Chelidonium majus. Chelidonium majus did not change the number of punished drinking episodes in a dose of $75 \mathrm{mg} / \mathrm{ml}$ (Table 3). In a dose of $150 \mathrm{mg} / \mathrm{kg}$ the extract significantly increased the number of punished drinking episodes (Table 3). However, the effect was not apparent in a high dose of $300 \mathrm{mg} / \mathrm{kg}$ (Table 3).

Table-3

Anxiolytic effect of medicinal plants in the conflict situation test

\begin{tabular}{|c|c|c|c|}
\hline Treatment & Dose & $\begin{array}{c}\text { Number of } \\
\text { punishments }\end{array}$ & $\begin{array}{l}\text { Moving } \\
\text { activity }\end{array}$ \\
\hline Normal saline & $10 \mathrm{ml} / \mathrm{kg}$ & $2.75 \pm 0.46$ & $7.2 \pm 0.83$ \\
\hline Corydalis Sib. & $75 \mathrm{mg} / \mathrm{kg}$ & $3 \pm 0.57$ & $7.6 \pm 0.57$ \\
\hline Corydalis Sib. & $150 \mathrm{mg} / \mathrm{kg}$ & $3 \pm 0.71$ & $9.96 \pm 0.61$ \\
\hline Chelidonium M. & $75 \mathrm{mg} / \mathrm{kg}$ & $2.5 \pm 0.54$ & $7.25 \pm 0.81$ \\
\hline Chelidonium M. & $150 \mathrm{mg} / \mathrm{kg}$ & $3.8 \pm 0.83^{*}$ & $9.1 \pm 0.66$ \\
\hline Normal saline & $10 \mathrm{ml} / \mathrm{kg}$ & $1.33 \pm 0.51$ & $4.8 \pm 0.83$ \\
\hline Chelidonium M & $300 \mathrm{mg} / \mathrm{ml}$ & $2.2 \pm 0.91$ & $5 \pm 0.84$ \\
\hline $\begin{array}{l}\text { Astragalus Mon } \\
\text { (aerial part) }\end{array}$ & $75 \mathrm{mg} / \mathrm{kg}$ & $2.25 \pm 0.51$ & $5.25 \pm 0.95$ \\
\hline $\begin{array}{l}\text { Astragalus Mon } \\
\text { (aerial part) }\end{array}$ & $150 \mathrm{mg} / \mathrm{kg}$ & $2.5 \pm 0.51$ & $5.5 \pm 0.83$ \\
\hline
\end{tabular}


Extracts of Chelidonium majus, aerial part of Astragalus mongolicus, and Corydalis sibirica were administreted (orally), 60 min before the test. Values are the mean \pm SEM for 6 mice. ${ }^{*} \mathrm{P}<0.05$, compared to control, by Student's t-Test

\section{Nootropic activity}

Animals receiving $300 \mathrm{mg} / \mathrm{kg}$ of the extract of Corydalis sibirica increased, the observed time of CAR, yet this effect did not reach statistical significance. Administration of Scutellaria baicalensis in a dose of $150 \mathrm{mg} / \mathrm{kg}$ produced amnesia as seen from reduction in the observed CAR. However, in a higher dose of $300 \mathrm{mg} /$ $\mathrm{kg}$, Scuttelatia baicalensis increased significantly $(\mathrm{P}<0.05)$ the latency period, producing better retention and recovery in this dose (Table 4). Chelidonium majus significantly decreased the latency period in a dose of $150 \mathrm{mg} / \mathrm{ml}$, but a dose of $300 \mathrm{mg} / \mathrm{ml}$ significantly increased the latency $(\mathrm{P}<005)$ compared to control group (Table 4).

\section{Table-4}

Nootropic activity of medicinal plants in the passive avoidance test

\begin{tabular}{||l|l|l||}
\hline Treatment & Dose & Latency period (sec) \\
\hline \hline Normal saline & $10 \mathrm{ml} / \mathrm{kg}$ & $12.06 \pm 1.5$ \\
\hline \hline Corydalis S & $300 \mathrm{mg} / \mathrm{kg}$ & $17.13 \pm 3.8$ \\
\hline \hline Sc. Baicalin & $150 \mathrm{mg} / \mathrm{kg}$ & $3.86 \pm 0.98^{*}$ \\
\hline \hline Sc. Baicalin & $300 \mathrm{mg} / \mathrm{kg}$ & $81.6 \pm 15.98^{*}$ \\
\hline \hline Chelidonium M. & $150 \mathrm{mg} / \mathrm{kg}$ & $114 \pm 33.29^{*}$ \\
\hline \hline Chelidomium M & $300 \mathrm{mg} / \mathrm{ml}$ & $5.3 \pm 1.98^{*}$ \\
\hline
\end{tabular}

Extracts of Chelidonium majus, Scutellaria majus and Corydalis sibirica were administered orally, 60 minute before the test. Values are the mean \pm SEM for 6 mice. ${ }^{*} \mathrm{P}<0.05$, compared to control, by Student's t-Test

\section{Antioxidant activity}

The generation of hydroxyl radicals by the $\mathrm{Fe}^{2+}$ /ascorbate/EDTA/ $\mathrm{H}_{2} \mathrm{O}_{2}$ system was found to be reduced in the presence of extracts of Astragalus Mongolicus or Chelidonium majus. ESR analysis demonstrated that extracts were capable of inhibiting the generation of hydroxyl radicals and lipid radicals. These findings suggest that extracts of medicinal herbs contain a low-molecular-weight bioactive factor that might promote survival of CNS neurons through the attenuation of free radical-mediated insults. 
The extract of the root Astragalus mongolicus at concentrations of 4.5, 9, 18, $37,75,150$, and $300 \mathrm{mg} / \mathrm{ml}$ reduced the generation of the hydroxyl radicals in a dose-dependent manner. The quantity of the extract needed for $50 \%$ inhibition of the generation of hydroxyl radicals was found to be $9 \mathrm{mg} / \mathrm{ml}$ (Fig. 1). A similar effect was produced by the aerial part of Astragalus mongolicus (Fig. 2), which in a concentration of $6 \mathrm{mg} / \mathrm{ml}$ was found to scavenge $50 \%$ of the generated hydroxyl radicals. The highest inhibition (95.9\%) of the generation was at a concentration of $12 \mathrm{mg} / \mathrm{ml}$. Meanwhile, for the root of Astragalus mongolicus, the greatest inhibition $(95.6 \%)$ of the generation of hydroxyl radicals was seen in a higher concentration of $150 \mathrm{mg} / \mathrm{ml}$. This result indicates that hydroxyl radicals scavenging effect of aerial part of Astragalus mongolicus is stronger than the effect of the root (Figs. 1 and 2).
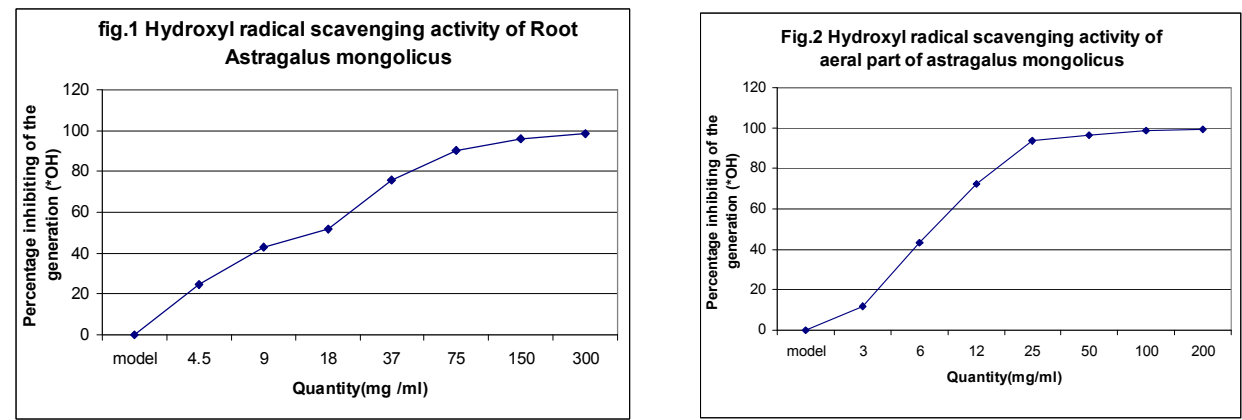

The scavenging effect of the root of Astragalus mongolicus on lipid radicals started from a lower concentration of $0.62 \mathrm{mg} / \mathrm{ml}$ and increased to $300 \mathrm{mg} / \mathrm{ml}$. A concentration of $4.8 \mathrm{mg} / \mathrm{ml}$ of the extract inhibited $40 \%$ of the generation of lipid radicals. The highest $(83.5 \%)$ inhibition of the generation of lipid radicals was in a concentration of $18 \mathrm{mg} / \mathrm{ml}$ (Fig. 3).

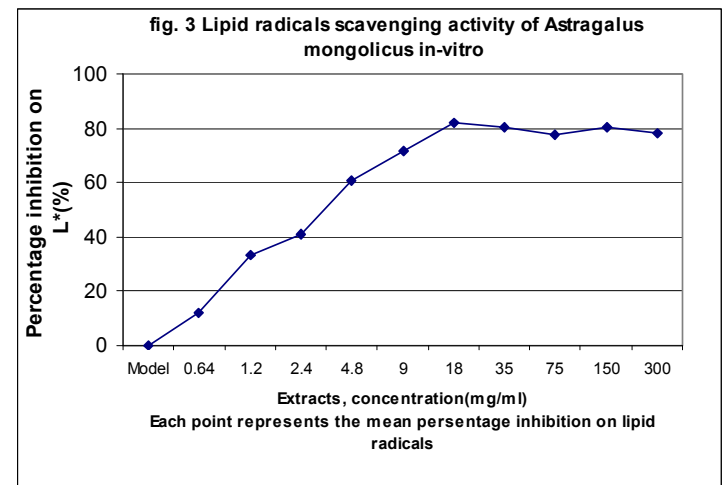


The hydroxyl radical scavenging activity of Chelidonium majus was seen at a concentration of $25 \mathrm{mg} / \mathrm{ml}$ and increased to $200 \mathrm{mg} / \mathrm{ml}$ of the extract. A concentration of $66 \mathrm{mg} / \mathrm{ml}$ caused a $50 \%$ inhibition of the generation of hydroxyl radicals (Fig. 4).

A concentration of $17 \mathrm{mg} / \mathrm{ml}$ of extract was without effect on the generation of hydroxyl radicals.

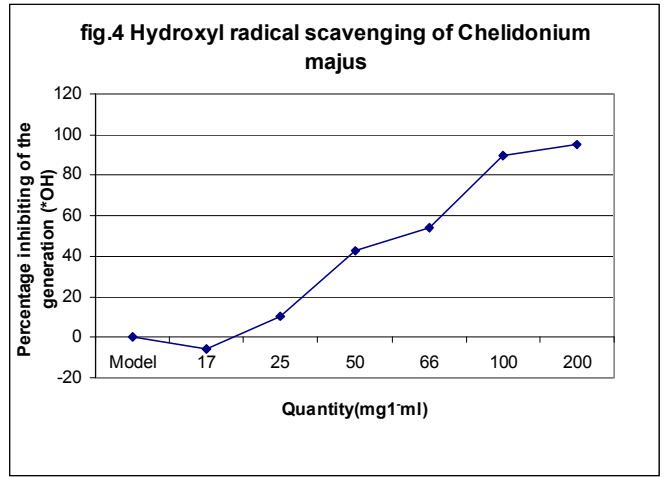

The inhibitory effect of Chelidonium majus on lipid radicals started from a dose of $0.62 \mathrm{mg} / \mathrm{ml}$ increasing to $200 \mathrm{mg} / \mathrm{ml}$. A concentration of $4 \mathrm{mg} / \mathrm{ml}$ caused over $60 \%$ inhibition of lipid radical generation. The highest ( $96.8 \%$ ) inhibition of the generation of lipid radicals was found at a concentration of $20 \mathrm{mg} / \mathrm{ml}$ (Fig. 5).

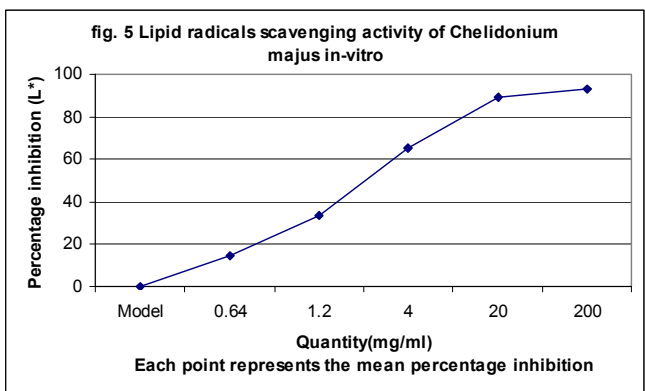

\section{Discussion}

Reports indicate that antioxidant activity is frequently accompanied by antiepileptic effects (Rubin JJ, 1980, Levy SL, 1990, Uchida S, 1987 ).

Concerning epileptic seizures, excitatory amino acid receptor activation by glutamate or N-methyl-D-aspartic acid (NMDA) has been known to accompany generation of reactive oxygen species (ROS), and reactive nitrogen species (RNS)(Lancelot E, Lecanu L 1998,Gunasekar PG 1995).

ROS and RNS induced by neurotransmitter and receptor disorders, iron ions and/or neurotoxins, result in neuronal disorders which lead to epileptic focus formation (Mori. A 2004). Antioxidants inhibit ROS- and RNS-induced neuronal damage, and prevent epileptic focus formation (Mori A. 2004, 1992). Less is known about 
anticonvulsant effects of Chelidonium majus, Astragalus mongolicus, Scutellaria baicalensis and Corydalis sibirica on GABAergic seizures, although it has been proposed that they possessed wide scavenging of free radicals. Therefore we purposed to verify antiepileptic effect in PTZ and MES models and assess neuropharmacological and neuroprotective effects.

In the present study, we have found that Astragalus mongolicus possesses a significant dose-dependent scavenging effect on hydroxyl and lipid radicals by an in vitro ESR technique. Astragalus mongolicus has anticonvulsant activities in PTZ and MES models, but these were less potent than similar effects of Scutellaria baicalensis extract. Scutellaria Baicalensis has been reported to show an anticancer effect, a scavenging of ROS generation (Gao D 1998) and free radical action ( Hamada H 1993). Therefore, we examined its effect in behavioral tests. The Scutellaria baicalensis extract in a dose of $300 \mathrm{mg} / \mathrm{kg}$ was shown to decrease experimental correlates of memory loss which could be due to its central GABAergic activitiy apart from its free radical scavenging mechanisms. Epilepsy causes loss of memory, and an antiamnestic effect is an common property for pharmacolotical treatments of epilepsy disorders. Furthermore, the antioxidant activities were correlated with the nootropic activity of the extract, consistent with postulated roles of stress and free radicals in the loss of memory (Jodar L,1995). The Scutellaria baicalensis extract decreased the latency period of CAR, consistent with a loss in memory, but it may be explained by a sedative effect of Scutellaria baicalensis extract. The Scutellaria baicalensis extract has demonstrated a significant anticonvulsant effect in PTZ and MES models, indicating an effect on the GABAergic system.

In the present study Chelidonium majus has been demonstrated to scavenge hydroxyl radicals and lipid radicals by ESR. By CAR test, Chelidonium majus extract was shown to have a significant antiamnestic effect, increasing the latency period in a dose of $150 \mathrm{mg} / \mathrm{ml}$. Reports indicated that Chelidonium majus also significantly inhibited acetylcholinesterase activity (Aldarmaa 2004). However, the extract supported a loss memory in a dose of $300 \mathrm{mg} / \mathrm{kg}$. Chelidonium majus extract had no influence on seizures in PTZ and MES models. By the conflict situation test Chelidonium majus didn't show an anxiolytic effect.

Chemical compounds of Corydalis sibirica are similar to those of Chelidonium majus. We assessed the effect of Corydalis sibirica on behavioral tests. Corydalis sibirica had no effect on seizures induced by the PTZ model and on the number of the punishments in the conflict situation test. By CAR test, Corydalis sibirica did not affect significantly the latency period. These data indicated that Corydalis sibirica yields by efficiency from effects of Chelidonium majus.

\section{Acknowledgements}

This work was financially supported by a grant from World Health Organization. Grateful acknowledgements are made doctor B. Burmaa, Govind, for their 
encouragements and appreciation of the work and to Chinese and Russian Institutes for their help in the study. The kind gifts of chemical regent from prof. J. Martin(USA) and electrodes from G.M. Molodavkin( Russia) are greatly appreciated.

\section{Reference}

1. Bhargava KP, Singh N. Anti-stress activity of Ocimum sanctum Linn. Indian J Med Res. 1981, 73:443-451

2. Colombo ML, Bosisio E. Pharmacological activities of Chelidonium majus L. Pharmacol Res 1996, 33: 127-134.

3. Dandiya PC, Collumbine H. Studies on Acorus calamus (III): some pharmacological properties of the volatile oil. J Pharmacol Exp Ther. 1959, 125:353359.

4. Esch T, Stefano GB, Fricchione GL, Benson $\mathrm{H}$. The role of stress in neurodegenerative diseases and mental disorders. Neuroendocrinol Lett. 2002;23:199-208

5. Flausino OA Jr, Zangrossi H Jr, Salgado JV, Viana MB. Effects of acute and chronic treatment with Hypericum perforatum L. (LI 160) on different anxiety-related responses in rats. Pharmacology Biochemistry and Behaviour. 2002, 71:251-7.

6. Gao D, Tawa R, Masaki H, Okano Y, Sakurai H: Protective effects of baicalein against cell damade by reactive oxygen species. Chem Pharm Bull(Tokyo) 1998, 46: 1383-1387

7. Gilani AH, Aziz N, Khan MA, Shaheen F, Jabeen Q, Siddiqui BS, Herzig JW. Ethnopharmacological evaluation of the anticonvulsant, sedative and antispasmodic activities of Lavandula stoechas L. Journal of Ethnopharmacology. 2000, 71:1617.

8. Graf WD, Oleinik OE, Glauser TA, Maertens P, Eder DN Pippenger CE. Altered antioxidant activities in children with a serious side adverse experience related to valproic acid therapy. Neuropediatrics. 1998, 29:195-201.

9. Gomez-Vargas M, Nishibayashi-Asanuma S, Asanuma M, Kondo Y, Iwata E, Ogawa N. Brain Res. 1998, 790:202-228.

10. Hamada $\mathrm{H}$, Hiramatsu M, Edamatsu R, Mori A: Free radical scavenging action of baicalein. Arch Biochem Biophys 1993, 306(I): 261-266.

11. Hauser WA, Annegers JF, Kurland LT. Incidence of epilepsy and unprovoked seizures in Rochester, Minnesota: 1935-1984. Epilepsia. 1993, 34:453-468

12. Hussain MM, Sokomba EN, Shok M. Pharmacological effects of Gardenia erubescens in mice, rats and cats. Int J Pharmacogn. 1991, 29:94-100.

13. Kery RY, Horvath J, Nasz I. Antiviral alkaloid in chelidonium majus L. acta Pharm hung 1987, 57: 19-25

14. Kokate TG, Svensson BE, Rogawski MA. Anticonvulsant activity of neurosteroids: correlation with r-aminobutyric acid-evoked chloride current potentiation. J Pharmacol Exp Ther. 1994;270:1223-1229. 
15. Kbrekзi AE, Alpay F, Tanindi S, Gokcay E, Ozcan O, Akin R, et al. Plasma trace element, plasma glutathione peroxidase, and superoxide dismutase levels in epileptic children receiving AEDs therapy. Epilepsia. 1995, 36:600-604.

16. Jesberger JA, Richardson JS. Oxygen free radicals and brain dysfunction. Int J Neuro Sci. 1991, 57: 1-17.

17. Lenfeld J, Kroutil M, Marsalek E: Antiinflammatory activity of quatertnary benzophenanthridine alkaloids from Chelidonium majus. Plata. Med 1981, 43: 161 165.

18. Levy SL, Burnham WM and Hwang PA: An evaluation of the anticonvulsant effects of vitamin E. Epilepsy Res .1990, 6: 12-17.

19. Luszczki JJ, OEwi№der M, Parada-Turska J, Czuczwar SJ:Tiagabine synergistically interacts with gabapentin in the electroconvulsive threshold test in mice. Neuropsychopharmacology,2003, 28: 1817-1830

20. Luszczki JJ, Wyjcik-Жwik ${ }^{3} a$ J, Andres MM, Czuczwar SJ: Pharmacological and behavioral characteristics of interactions between vigabatrin and conventional antiepileptic drugs in pentylenetetrazole-induced seizures inmice: an isobolographic analysis. Neuropsychopharmacology. 2005, 30: 958-973.

21. Masuda Y, Ishizaki M, Shimizu M. Zonisamiode: Pharmacology and clinical efficacy in epilepsy.

22. Molodavkin GM, Aldarmaa J, Boronina TA. Behavioral and electrophysiological analysis of the anxiolytic effect of Astragalus mongolicus.Bull. Exper. Biology and Medicine. 1998, 32(4): 35-37.

23. Molodavkin GM, Aldarmaa J, Boronina TA. Property of Astragalus mongolicus. Clinical pharmacology, 2000, 6: 11-14.

24. Maertens P, Dyken P, Graf W, Pippenger C, Chronister R, Shah A. Free radicals, anticonvulsants and the neuronal ceroid lipofuscinosis. Am J Med Genet. 1995, 57:225-228.

25. Mori A., Hiramarsu M., and Yokoi I: Posttraumatic epilepsy, free radicals and antioxidant therapy; in free Radical in the Brain Aging, Neurological and Mental Disorders, Packer L, Prilipko L and Christen Y eds, Springer-Verlag, Berlin(1992) pp. 109-122.

26. Mori.A., Yokoi I. Natural antioxidants may prevent posttraumatic epilepsy: A Proposal based on experimental animal studies. Acta Med. Okayama. 2004, 58; 3 : $111-118$.

27. Rege NN, Thatte UM, Dhanukar SA. Adaptogenic properties of six rasayana herbs used in Ayurvedic medicine. Phytother Res. 1999, 13:275-291

28. Rubin JJ, Willmore LJ: Prevention of iron-induced epileptiform discharges in rats by treatment with antiperoxidant. Exp Neurol.1980, 31:63-69.

29. Sheth DP. Hypocalcemic seizures in neonates. Am J Emerg Med. 1997;15:141143.

30. Selye H. Syndrome produced by diverse nocuous agents. J Neuropsychiatry Clin Neurosci. 1998, 10:230-231 
31. Singh HK, Dhawan BN. Effect of Bacopa monniera (Brahmi) extract on avoidance responses in rats. J Ethnopharmacol. 1982, 5:205-214.

32. Vernault P, Chapouther G, de Carvalho LP, Simiand J, More M, Dodd RH, Rossier J:Benzodaizepine impairs and beta-carboline enchances performance in learning and memory tasks. Nature, 1986, 321: 864-866.

33. Verrotti A, Basciani F, Trotta D, Pomilio MP, Morgese G, Chiarelli F. Serum copper, zinc, selenium, glutathione peroxidase and superoxide dismutase levels in epileptic children before and after 1 year of sodium valproate and carbamazepine therapy. Epilepsy Res. 2002, 48:71-75.

34. Vogel, HG.; Vogel, WH. Drug Discovery and Evaluation, Pharmacological Assay. Springer, Berlin. 1997. pp. 260-261.

35. Vogel J R, Beer B, Clody D E. Psychopharmacologia. 1971, 21:1-7

36. Wagner H, Norr H, Winterhoff H. Plant Adaptogens. Phytomedicine. 1994,1:6376.

37. Ysksel A, Cengiz M, Seven M, Ulutin T. Erythrocyte glutathione, glutathione peroxidase, superoxide dismutase and serum lipid peroxidation in epileptic children with valproate and carbamzepine monotherapy. J Basic Clin Pharmacol. 2000, 11: 73-81. 